N

Faculty of Economic Sciences

Working Papers

No. $19 / 2011$ (59)

MICHAŁ BRZEZIŃSKI

ACCOUNTING FOR RECENT TRENDS IN ABSOLUTE POVERTY IN POLAND: A DECOMPOSITION ANALYSIS 


\title{
Accounting for recent trends in absolute poverty in Poland: A decomposition analysis
}

\author{
Michał Brzeziński \\ University of Warsaw \\ Faculty of Economic Sciences \\ e-mail: mbrzezinski@wne.uw.edu.pl
}

\begin{abstract}
This paper uses several decomposition of poverty and poverty changes to identify factors explaining recent changes in absolute income and consumption poverty in Poland during 1998-2008. Shapley decompositions of poverty changes into growth and redistribution components show that fast economic growth was the main source of a radical fall in absolute poverty since 2005 . Distributional changes had a more profound effect on absolute poverty during 1998-2005. Sectoral decompositions of poverty suggest that stagnant wages and pensions as well as growing unemployment were major factors accounting for increasing poverty between 1998 and 2005. Decompositions of poverty indices by income sources show that social insurance is the most effective income source in reducing poverty incidence in Poland, while social assistance is the most effective source in fighting intensity of poverty.
\end{abstract}

Keywords:

poverty, growth, inequality, poverty decompositions, transfers, Poland

JEL:

I32, P36

\section{Acknowledgements:}

This research was supported by the Polish Ministry of Science and Higher Education research grant under contract number N N112 016536. 


\section{Introduction}

The problem of poverty reduction in post-communist countries has been a matter of concern for many years (see, e.g., World Bank, 2000; 2005). While in most of the Eastern European and Central Asian countries high rates of economic growth during 1998-2003 have significantly reduced absolute poverty incidence (see, e.g., Chen and Ravallion, 2007), in other countries poverty rates have actually increased. According to Szulc (2008), the percentage of population living with consumption or income below the absolute poverty line increased in Poland during 1998-2003 by between 7 and $9 \%$ depending on the welfare measure used. This change was brought about by a slowing rate of economic growth (decreasing from 4.9\% in 1998 to $1.5 \%$ in 2002), rising unemployment rates (from 10.7 in 1998 to 19.6 in 2003) and a worsening income distribution (see Table 1).

Table 1. Aggregate economic indicators, Poland, 1998-2008

\begin{tabular}{llllllll}
\hline & $\begin{array}{l}\text { Growth } \\
\text { rate }\end{array}$ & $\begin{array}{l}\text { Inflation } \\
\text { rate }\end{array}$ & $\begin{array}{l}\text { Unemp. } \\
\text { rate }\end{array}$ & \multicolumn{2}{l}{ Gini index } & \multicolumn{2}{c}{ Relative poverty rate } \\
\cline { 5 - 8 } & & & Income & Cons. & Income & Cons. \\
\hline 1998 & 4.9 & 11.7 & 10.7 & 0.295 & 0.306 & 0.155 & 0.144 \\
1999 & 4.5 & 7.3 & 12.5 & 0.298 & 0.305 & 0.164 & 0.150 \\
2000 & 4.8 & 10.1 & 16.1 & 0.312 & 0.309 & 0.169 & 0.154 \\
2001 & 1.7 & 5.5 & 18.2 & 0.308 & 0.306 & 0.169 & 0.152 \\
2002 & 1.5 & 1.9 & 19.9 & 0.314 & 0.313 & 0.173 & 0.156 \\
2003 & 3.9 & 0.8 & 19.6 & 0.317 & 0.320 & 0.175 & 0.163 \\
2004 & 5.4 & 3.6 & 19.0 & 0.326 & 0.325 & 0.180 & 0.167 \\
2005 & 3.7 & 2.1 & 17.7 & 0.323 & 0.319 & 0.175 & 0.161 \\
2006 & 6.3 & 1.1 & 13.8 & 0.318 & 0.313 & 0.170 & 0.159 \\
2007 & 6.8 & 2.4 & 9.6 & 0.320 & 0.316 & 0.159 & 0.157 \\
2008 & 5.0 & 4.3 & 7.1 & 0.315 & 0.322 & 0.159 & 0.160 \\
\hline
\end{tabular}

Source: World Development Indicators , Polish CSO and own calculations.

Notes: The relative poverty line is equal to the $60 \%$ of median income or consumption.

The Gini coefficient of income inequality has been steadily increasing from 0.295 in 1998 to 0.317 in 2003. However, after 2003 the situation improved as growth rate has accelerated from $3.9 \%$ in 2003 to $6.8 \%$ in 2007 , while the unemployment rate has fallen to $7.1 \%$ in 2008. Moreover, income inequality as measured by the Gini coefficient stabilized around 0.32 . The absolute poverty rate as calculated by the Central Statistical Office (CSO 2009) dropped radically from $18.1 \%$ in 2005 to $10.6 \%$ in 2008. ${ }^{1}$ In effect, levels of absolute poverty in 2008 are much lower than in 1998 (see CSO 2009 and Table 3 in this paper). ${ }^{2}$

\footnotetext{
${ }^{1}$ These estimates are calculated with the so-called "legal" poverty line, which is an income threshold below which one is eligible for the social assistance payments. If the official "subsistence minimum" is assumed as a poverty line, then absolute poverty fell from $12.3 \%$ in 2005 to $5.6 \%$ in 2008 (CSO 2009).

${ }^{2}$ It should be noticed here that the changes in relative poverty, that is poverty calculated with relative poverty lines (i.e. equal to $60 \%$ of median income), were less profound (see Table 1). In fact, the levels of relative poverty in 2008 are close to those of 1998.
} 
The present paper applies a number of analytical decompositions of poverty and poverty changes to Polish household survey data in order to identify factors accounting for recent significant changes in absolute income and consumption poverty in Poland during 1998-2008. In particular, the paper attempts to discover what factors contributed to the radical fall in absolute poverty in Poland between 2005 and 2008. A decomposition of the Sen-Shorrocks-Thon index of poverty (Osberg and $\mathrm{Xu} 2000$ ) is performed in order to measure the impact of various dimensions of poverty (its incidence, intensity and inequality) on total poverty changes. Decompositions of poverty changes into growth and redistribution components using the so-called Shapley approach (see Datt and Ravallion 1992, Duclos and Arrar 2006, cha. 5.7) are used to separate contributions of economic growth and inequality to the observed poverty changes. We perform also sectoral decompositions of poverty changes (see Huppi and Ravallion 1991, Duclos and Arrar 2006, cha. 5.7) to analyze how overall poverty changes can be attributed to poverty changes within and across various socio-economic groups. Finally, we conduct poverty decompositions by income sources (Bibi and Duclos 2010) to find out which income components have been the most effective in reducing poverty during the recent years in Poland.

The paper is related to the substantial literature on poverty in Poland during the transition period. An exhaustive review of this literature is provided by Szulc (2008). Growth-redistribution decompositions of poverty changes in Poland were previously performed by Szulc (2000) and Paci et al. (2004). The present paper extend their results for the period between 2005 and 2008, when economic growth was particularly fast. Other recent attempts to account for factors behind poverty changes in Poland include Szulc (2009) and Morawski and Myck (2010), who analyze, respectively, the impact of social transfers on poverty in Poland and the distributional consequences of recent changes in direct personal taxation (i.e. introduction of the Child Tax Credit in Poland in 2007).

The rest of the paper is organized as follows. The next section presents poverty indices and decomposition methodologies used in the paper. Polish household survey data are described next and empirical analyses with discussion follow. The last section concludes.

\section{Methods}

\section{Poverty indices}

This paper uses five indices of poverty, which display different sensitivities to various dimensions of poverty. ${ }^{3}$ The first three belong to the well-known Foster-GreerThorbecke (FGT) family (Foster et al. 1984). For a population of size $N$, a vector of welfare indicators (i.e. incomes) $x=\left(x_{1}, x_{2}, \ldots, x_{N}\right)$, and a poverty line $z$, FGT indices are defined as:

\footnotetext{
${ }^{3}$ Theoretical properties of these and other poverty indices are thoroughly discussed by Zheng (1997) and Chakravarty (2009).
} 


$$
P_{F G T}=1 / N \sum_{i=1}^{q}\left(1-x_{i} / z\right)^{\alpha},
$$

where $q$ is the number of the poor, that is individuals with incomes not above the poverty line and $\alpha$ is the "poverty aversion" parameter. When $\alpha=0$, the FGT index is simply the most popular poverty measure - the headcount ratio giving the proportion of a population that is poor. For $\alpha=1$, the FGT measure is the average poverty gap showing the average shortfall of income from the poverty line. While the headcount ratio measures only the proportion of the poor (incidence of poverty), average poverty gap is sensitive both to the number of the poor and the intensity of poverty. However, it is still insensitive to the inequality among the poor. Squared poverty gap, that is the FGT for $\alpha=2$, captures this last dimension of poverty as well, as it involves the headcount ratio, the product of headcount ratio and average poverty gap and the coefficient of variation of income among the poor (see, e.g., Chakravarty 2009, p. 66).

The fourth index of poverty used in this paper is the Watts index (1968), which is defined as

$$
P_{W}=1 / N \sum_{i=1}^{q} \log \left(z / x_{i}\right) .
$$

As the only measure used in this paper, the Watts poverty index is in a small class of poverty measures that satisfy all basic axioms proposed for a good poverty index (Zheng 1997).

The last index used is the Sen-Shorrocks-Thon (SST) index, which was initially proposed by Sen (1976), modified by Shorrocks (1995) and approaches Thon (1979) poverty measure as $N$ and $q$ become large. The SST index is defined as

$$
P_{S S T}=1 / N^{2} \sum_{i=1}^{q}(2 * N-2 * i+1)\left(z-x_{i}\right) / z .
$$

The main advantage of this index is that, similarly to squared poverty gap, it takes into account all "three I's of poverty", that is its incidence, intensity and inequality.

\section{Decomposition methodologies}

\section{SST index decomposition}

Osberg and Xu (2000) show that the SST index can be decomposed as

$$
P_{S S T}=P_{F G T_{0}} P_{P G R}(1+G),
$$

where $\mathrm{P}_{\mathrm{PGR}}$ is the average poverty gap ratio of the poor:

$$
P_{P G R}=1 / q \sum_{i=1}^{n}\left(1-x_{i} / z\right),
$$

and $G$ is the Gini index of inequality calculated for the poverty gap ratios of the whole population. Osberg and $\mathrm{Xu}$ (2000) further decompose a change in $\mathrm{P}_{\mathrm{SST}}$ over two points in time as

$$
\Delta \ln P_{S S T}=\Delta \ln \left(P_{F G T(0)}\right)+\Delta \ln \left(P_{P G R}\right)+\Delta \ln (1+G),
$$


where $\Delta$ is the first difference operator. Therefore, a percentage change in $\mathrm{P}_{\mathrm{SST}}$ can be expressed as the sum of the percentage changes in the headcount ratio, average poverty gap ratio among the poor, and Gini index of inequality in the poverty gap ratios among all members of the society. The decomposition helps to identify whether poverty changes occur because of the increasing number of the poor, or because the poor are getting poorer, or because inequality among the poor increases, or because of some combination of these factors.

\section{Growth-redistribution decompositions of poverty changes}

In the literature on the theoretical links between growth, poverty and inequality, it has been shown that absolute poverty reduction in any given country is fully determined by the rate of growth in the mean income of the population and the change in the inequality of income distribution (Bourguignon, 2004). Several authors developed poverty decomposition methodologies, which allow for the measurement of separate impacts of income growth and changes in redistribution (income inequality) to the variation in poverty measures (e.g., Datt and Ravallion, 1992; Kakwani, 2000; Shorrocks, 1999). This kind of decompositions help, therefore, to identify whether economic growth and inequality changes work hand in hand in alleviating poverty or if their impact is different. In this paper we apply growth-redistribution decomposition of poverty changes proposed by Shorrocks (1999), which relies on the cooperative game-theoretic concept of the Shapley value. ${ }^{4}$ For a fixed poverty line $z$ and the $\operatorname{FGT}(z, \alpha)$ family of poverty indices, the change in poverty between periods $t$ and $t+n$ with mean incomes $\mu_{t}$ and $\mu_{t+n}$, respectively, can be expressed as a sum of a "growth" (difference in mean income) effect, $G$, and of a "redistributive" (difference in relative income shares) effect, $D$ :

$$
\begin{aligned}
& F G T^{t+n}(z, \alpha)-F G T^{t}(z, \alpha)=G+D \\
& G=0.5\left[\left(F G T^{t}\left(z \frac{\mu_{t}}{\mu_{t+n}}, \alpha\right)-F G T^{t}(z, \alpha)\right)+\left(F G T^{t+n}(z, \alpha)-F G T^{t+n}\left(z \frac{\mu_{t+n}}{\mu_{t}}, \alpha\right)\right)\right] \\
& D=0.5\left[F G T^{t+n}\left(z \frac{\mu_{t+n}}{\mu_{t}}, \alpha\right)-F G T^{t}(z, \alpha)+\left(F G T^{t+n}(z, \alpha)-F G T^{t}\left(z \frac{\mu_{t}}{\mu_{t+n}}, \alpha\right)\right)\right] .
\end{aligned}
$$

For the growth-redistribution poverty decomposition using the Shapley value, the growth effect, $G$ (the redistributive effect, $D$ ), is the average of two growth effects (two redistributive effects) calculated with different choices for the reference period distribution.

\footnotetext{
${ }^{4}$ Identical poverty decomposition was independently derived in an axiomatic framework by Kakwani (2000). Another widely used methodology developed by Datt and Ravallion (1992) is inexact (includes a residual term) and asymmetrical (uses the concept of "reference period", which leads to asymmetrical results for the choice of initial and final period of analysis). See Duclos and Arrar (2006, cha. 5.7 and Appendix 4.7) for a complete discussion of the Shapley value concept in the context of decomposing poverty.
} 
The purpose of sectoral decompositions is to find out what share of overall poverty changes can be attributed to changes in sectoral composition of the population and what share can be attributed to changes in poverty across chosen sectors. The most useful in practice sectoral decomposition of poverty changes was introduced by Duclos and Araar (2006, cha. 5.7.2) as an exact sum of within-sector poverty effects and across-group poverty effects. ${ }^{5}$ For a population consisting of $k$ sectors with population shares $\phi(k)$, a fixed poverty line $z$ and the $\operatorname{FGT}(z, \alpha)$ family of poverty indices, the change in poverty between periods $t$ and $t+n$ can be expressed as

$$
\begin{aligned}
& F G T^{t+n}(z, \alpha)-F G T^{t}(z, \alpha)=W+A, \\
& W=\sum_{k}^{K} \bar{\phi}(k)\left(F G T^{t+n}(z, \alpha)-F G T^{t}(z, \alpha)\right), \\
& A=\sum_{k}^{K} \overline{F G T}(z, \alpha)\left(\phi_{t+n}(k)-\phi_{t}(k)\right),
\end{aligned}
$$

where $\bar{\phi}(k)=0.5\left(\phi_{t+n}(k)+\phi_{t}(k)\right)$ and $\overline{F G T}(z, \alpha)=0.5\left(F G T^{t+n}(z, \alpha)+F G T^{t}(z, \alpha)\right)$.

The sectors can be defined along any relevant socio-economic dimension, that is sectors could be demographic groups, sexes, employers in various sectors of the economy, etc. This decomposition can be therefore used, for example, to analyze how variations in the size and in the poverty of various sectors of the economy over time explain changes in total poverty for the economy over time.

\section{Poverty decompositions by income sources}

The final poverty decomposition used in this paper concerns the impact of various income components (e.g., market income, social insurance, social transfers, etc.) on the total poverty reduction. The problem of establishing the separate impact of every income component on poverty reduction was recently taken up by Bibi and Duclos (2010). They propose to calculate the contribution to poverty reduction of a given income component $c$ by estimating the fall in poverty when $c$ is conceptually added to the initial income. Since such a procedure depends on what is chosen as an initial income and on the order of inclusion of various income sources, Bibi and Duclos (2010) choose the initial income to be nil and require that an acceptable order of inclusion have to fulfil a number of desirable axioms. It turns out that the axioms are satisfied only by the order specified by the Shapley value. ${ }^{6}$ According to this solution, for the population of $N$ persons and $T$ income sources, the poverty impact of an income source $y_{i}, \pi_{\alpha}\left(y_{i}, z\right)$, when poverty is measured by the $\operatorname{FGT}(z, \alpha)$ index, is the expected value of its marginal contribution when $y_{i}$ is added to every of the various possible subsets of income components that can be constructed from the set of all

\footnotetext{
${ }^{5}$ The first decomposition of this kind was proposed by Huppi and Ravallion (1991). Unfortunately this decomposition suffers from a similar drawback as the growth-redistribution decomposition of Datt and Ravallion (1992) (see footnote 4).

${ }^{6}$ See Duclos and Arrar (2006, Appendix 4.7) for an introduction to the use of the Shapley value concept in distributive analysis.
} 
income components. Further, Bibi and Duclos (2010) introduce a measure of poverty effectiveness of a (positive) income source by dividing its poverty impact, $\pi_{\alpha}\left(y_{i}, z\right)$, by the size of that source measured by the average of $y_{i}$ normalized by the poverty line $z$ :

$$
\Gamma_{\alpha}\left(y_{i}, z\right)=100 \frac{\pi\left(y_{i}, z\right)}{\bar{y}_{i}},
$$

where $\bar{y}_{i}=\frac{100}{z N} \sum_{i=1}^{N} y_{i}$.

This last measure can be used to compare which income sources are most effective in reducing poverty relative to their monetary value. In case of social expenditures, $\Gamma_{\alpha}\left(y_{i}, z\right)$ may be used to verify which social transfers are most costeffective in reducing poverty. On the other hand, as suggested by Bibi and Duclos (2010), low values of $\Gamma_{\alpha}\left(y_{i}, z\right)$ for market income may suggest that the growth in market income earned by households has a rather low power to reduce poverty.

\section{Data}

The paper uses micro-data from the Household Budget Surveys (HBS) conducted yearly by the Polish Central Statistical Office (CSO), which is representative for the Polish population since 1993. The HBS uses a two-stage stratified sampling scheme. The detailed information about sample design (weighting, stratification, and clustering) is used in this paper to calculate correct point estimates of poverty measures and their corrected standard errors. ${ }^{7}$ The complete description of the HBS sample design and its other features can be found in Kordos et al. (2002) and CSO (2009).

We use two standard of living indicators: income and consumption. Household net disposable income (i.e. post-tax-and-transfer income) is the main income concept used. It includes cash wages and salaries, self-employment income (including farm income), cash property income, social transfers (including social insurance and social assistance) and other income. Income taxes, mandatory payroll taxes and gifts donated to other households are not included. As a consumption measure we use total expenditures on consumer goods and services, which include expenditures on food, clothing, housing, health care, transportation and communication, culture and recreation and education. The measure includes expenses on durables and natural consumption.

We consider the individual as the main unit of analysis. In order to obtain personal distributions, all household observations are weighted by the product of household weights provided by the HBS and household sizes. We use consumer price indices provided by the CSO to adjust for differences in the prices faced by households in different years and/or regions. For income distributions, we use monthly price indices of consumer goods and services specific for five socio-

\footnotetext{
${ }^{7}$ As shown by Howes and Lanjouw (1998), ignoring complexity of survey design can lead to significantly underestimated standard errors of poverty measures.
} 
economic groups. In case of consumption expenditures, we use quarterly consumer price indices for voivodships and for 12 categories of consumption expenditures. All distributions have been expressed in 2008 price levels. Finally, in order to adjust for the size and composition of households, all incomes are equivalised using the original OECD equivalence scale, which assigns weights 0.7 to any adult household member beyond the first and 0.5 to children under 14 years old. Szulc (2006) argued convincingly that for Poland the original OECD scale is more appropriate than the modified OECD scale and other non-estimated scales as economies of scale in Polish households are rather low due to the relatively high expenditures on food and relatively low expenditures on housing.

In order to compute poverty indices, the "corrected social minimum" for 2003 is used as an absolute poverty line. This is taken from Szulc (2008) and updated to 2008 prices using the overall consumer price index.

\section{Empirical results and discussion}

The descriptive statistics for our samples in chosen years $(1998,2002,2005,2008)$ are shown in Table 2. For both welfare indicators one can observe clearly two subperiods corresponding to the phases of the business cycle. During 1998-2002 both mean (and median) income and consumption expenditures were slightly declining, while during 2002-2005 their rates of growth were positive but very low. This is somewhat inconsistent with lowering but positive rates of economic growth taken from National Accounts Statistics (NAS) during 1998-2002 and with significantly higher rates of growth during 2003-2005 (see Table 1). Possible explanations of these inconsistencies between NAS and household surveys include the unusually high investment accumulation in Poland over the 1990s and the relatively high export rate (Paci et al. 2004) as well as measurement errors and different coverage and accounting practices (Ravallion 2003).

Table 2. Descriptive statistics for HBS samples

\begin{tabular}{lllll}
\hline & 1998 & 2002 & 2005 & 2008 \\
\hline Income & 1054.2 & 1022.2 & 1030.8 & 1319.7 \\
Mean & 916.1 & 872.5 & 867.0 & 1112.0 \\
Median & 60.9 & 62.9 & 62.3 & 48.7 \\
Mean income of the poor & 476.7 & 461.5 & 460.1 & 478.1 \\
Mean poverty gap & 159.3 & 174.4 & 178.0 & 167.1 \\
Consumption & & & & \\
Mean & 943.5 & 912.9 & 917.4 & 1113.2 \\
Median & 790.6 & 760.8 & 758.9 & 915.4 \\
Poverty line as \% of mean & 68.1 & 70.4 & 70.0 & 57.7 \\
Mean cons. of the poor & 480.8 & 468.7 & 466.7 & 489.1 \\
Mean poverty gap & 154.4 & 163.7 & 167.2 & 148.7 \\
& & & & \\
Sample size (persons) & 100775 & 99869 & 107124 & 109819 \\
\hline
\end{tabular}

Source: Own calculations using HBS data

Notes: Poverty line $=642.5$ PLN $($ in 20081 USD $=2.41$ PLN, 1 EUR $=3.42$ PLN) 
However, for the recent period between 2005 and 2008, fast GDP growth went hand in hand with rapid growth of living standards as estimated form household surveys. In particular, mean income increased by $28 \%$ during $2005-2008$, while mean consumption by $21 \%$. For these reasons, we will refer to the 1998-2005 period as a stagnation period and we will label the subsequent years as fast-growth period. Table 2 shows also that mean levels of both standard of living indicators calculated for the poor with our poverty line followed closely the behaviour of the overall means during the stagnation period, but did not keep the pace of overall means during the fastgrowth years. Mean poverty gaps were also decreasing slower than overall means were rising during 2005-2008.

Table 3 shows the trends in aggregate poverty indices. Poverty has increased during 1998-2005 irrespectively of the welfare indicator and poverty index used. In case of the headcount ratio, poverty increased by $22 \%$ and $12 \%$ for income and consumption, respectively. During the period of fast growth between 2005 and 2008 poverty has fallen radically - in case of the headcount ratio the fall was $50 \%$ (income) and $34 \%$ (consumption). For other indices, like $\mathrm{FGT}_{2}$ and SST, the changes were even greater.

Table 3. Aggregate poverty indices for Poland, 1998, 2002, 2005, and 2008

\begin{tabular}{|c|c|c|c|c|}
\hline Poverty index & 1998 & 2002 & 2005 & 2008 \\
\hline \multicolumn{5}{|l|}{ Income } \\
\hline Headcount ratio & $\begin{array}{l}0.237 \\
(0.230 ; 0.244)\end{array}$ & $\begin{array}{l}0.281 \\
(0.273 ; 0.289)\end{array}$ & $\begin{array}{l}0.289 \\
(0.282 ; 0.296)\end{array}$ & $\begin{array}{l}0.144 \\
(0.139 ; 0.149)\end{array}$ \\
\hline $\mathrm{FGT}_{1}$ & $\begin{array}{l}0.061 \\
(0.059 ; 0.064)\end{array}$ & $\begin{array}{l}0.079 \\
(0.076 ; 0.082)\end{array}$ & $\begin{array}{l}0.082 \\
(0.079 ; 0.085)\end{array}$ & $\begin{array}{l}0.037 \\
(0.035 ; 0.039)\end{array}$ \\
\hline $\mathrm{FGT}_{2}$ & $\begin{array}{l}0.025 \\
(0.023 ; 0.026)\end{array}$ & $\begin{array}{l}0.034 \\
(0.032 ; 0.035)\end{array}$ & $\begin{array}{l}0.035 \\
(0.034 ; 0.037)\end{array}$ & $\begin{array}{l}0.016 \\
(0.015 ; 0.017)\end{array}$ \\
\hline Watts & $\begin{array}{l}0.084 \\
(0.080 ; 0.088)\end{array}$ & $\begin{array}{l}0.110 \\
(0.105 ; 0.115)\end{array}$ & $\begin{array}{l}0.114 \\
(0.110 ; 0.119)\end{array}$ & $\begin{array}{l}0.053 \\
(0.050 ; 0.056)\end{array}$ \\
\hline Sen-Shorrocks-Thon & $\begin{array}{l}0.114 \\
(0.110 ; 0.118)\end{array}$ & $\begin{array}{l}0.145 \\
(0.140 ; 0.150)\end{array}$ & $\begin{array}{l}0.150 \\
(0.145 ; 0.154)\end{array}$ & $\begin{array}{l}0.071 \\
(0.067 ; 0.074)\end{array}$ \\
\hline \multicolumn{5}{|l|}{ Consumption } \\
\hline Headcount ratio & $\begin{array}{l}0.336 \\
(0.327 ; 0.344)\end{array}$ & $\begin{array}{l}0.369 \\
(0.360 ; 0.378)\end{array}$ & $\begin{array}{l}0.377 \\
(0.369 ; 0.385)\end{array}$ & $\begin{array}{l}0.247 \\
(0.239 ; 0.254)\end{array}$ \\
\hline $\mathrm{FGT}_{1}$ & $\begin{array}{l}0.084 \\
(0.081 ; 0.088)\end{array}$ & $\begin{array}{l}0.100 \\
(0.096 ; 0.103)\end{array}$ & $\begin{array}{l}0.103 \\
(0.100 ; 0.106)\end{array}$ & $\begin{array}{l}0.059 \\
(0.056 ; 0.061)\end{array}$ \\
\hline $\mathrm{FGT}_{2}$ & $\begin{array}{l}0.031 \\
(0.029 ; 0.032)\end{array}$ & $\begin{array}{l}0.038 \\
(0.037 ; 0.040)\end{array}$ & $\begin{array}{l}0.040 \\
(0.038 ; 0.042)\end{array}$ & $\begin{array}{l}0.021 \\
(0.020 ; 0.022)\end{array}$ \\
\hline Watts & $\begin{array}{l}0.107 \\
(0.103 ; 0.111)\end{array}$ & $\begin{array}{l}0.129 \\
(0.124 ; 0.134)\end{array}$ & $\begin{array}{l}0.134 \\
(0.129 ; 0.139)\end{array}$ & $\begin{array}{l}0.074 \\
(0.071 ; 0.077)\end{array}$ \\
\hline Sen-Shorrocks-Thon & $\begin{array}{l}0.151 \\
(0.146 ; 0.156)\end{array}$ & $\begin{array}{l}0.176 \\
(0.171 ; 0.182)\end{array}$ & $\begin{array}{l}0.182 \\
(0.177 ; 0.1867)\end{array}$ & $\begin{array}{l}0.109 \\
(0.105 ; 0.113)\end{array}$ \\
\hline
\end{tabular}

Source: Own calculations using the HBS data.

Notes: 95\% confidence intervals calculated with asymptotic standard errors (see Kakwani 1993, Howes and Lanjouw, 1998) are given in parentheses. Confidence interval for the SST index is calculated using 500 bootstrap replications accounting for complex survey features of the HBS (see Kolenikov 2010). Poverty line $=642.5$ PLN (in 20081 USD = 2.41 PLN, 1 EUR = 3.42 PLN). 
All changes in poverty indices between 1998 and 2005 and between 2005 and 2008 are statistically significant. The final levels of all poverty indices in 2008 are much lower than their levels in 1998. These results are fairly robust to the choice of poverty line - we have performed these calculations with 20\% higher and $20 \%$ lower poverty lines achieving fairly similar results. Therefore, we may conclude that the period between 1998 and 2008 may be divided into a sub-period of stagnation between 1998 and 2005, during which economic growth was slowing down and absolute poverty increased sizeably and the fast-growth period from 2005 to 2008 characterized by a rapid fall in absolute poverty. The rest of this section is concerned with explaining the forces behind these significant poverty changes.

Table 4 presents the decomposition of the SST index into the three components. For both sub-periods studied changes in the inequality component play a rather negligible role. The results suggest that poverty changes for both standard of living indicators and for both sub-periods studies were driven mostly by changes in the proportion of the poor (poverty headcount ratio). For example, during the rapid fall in poverty between 2005 and 2008, the fall in the headcount ratio accounted for $93 \%$ and $83 \%$ of the overall decline in SST index for income and consumption, respectively.

Table 4. Decomposition of the Sen-Shorrocks-Thon poverty index

\begin{tabular}{|c|c|c|c|c|c|}
\hline & \multirow[t]{2}{*}{$\Delta$ SST Index } & \multirow[t]{2}{*}{$\Delta \ln (\mathrm{SST})$} & \multicolumn{3}{|c|}{ Decomposition of $\Delta \ln (\mathrm{SST})$} \\
\hline & & & $\Delta \ln \left(\mathrm{FGT}_{0}\right)$ & $\Delta \ln (\mathrm{PGR})$ & $\Delta \ln (1+\mathrm{G}(\mathrm{x}))$ \\
\hline \multicolumn{6}{|l|}{ Income } \\
\hline 1998-2005 & $0.036^{*}$ & $0.273^{*}$ & $0.196^{*}$ & $0.096^{*}$ & $-0.019^{*}$ \\
\hline 2005-2008 & $-0.079 *$ & $-0.749 *$ & $-0.695^{*}$ & $-0.104 *$ & $0.050 *$ \\
\hline \multicolumn{6}{|c|}{ Consumption } \\
\hline 1998-2005 & $0.031 *$ & $0.182^{*}$ & $0.115^{*}$ & $0.084 *$ & $-0.016^{*}$ \\
\hline 2005-2008 & $-0.073^{*}$ & $-0.512 *$ & $-0.423^{*}$ & $-0.137 *$ & $0.048 *$ \\
\hline
\end{tabular}

Source: Own calculations using the HBS data.

Notes: * denotes statistical significance at the $95 \%$ confidence level calculated using bootstrap methods (see Notes to Table 3).

Increases in the average poverty gap ratio of the poor played a more pronounced role during poverty rise between 1998 and 2005. They accounted for 35\% (in case of income) and $46 \%$ (in case of consumption) of the overall poverty changes during this period.

The results for growth-redistribution poverty decompositions are presented in Table 5. We start with the analysis for the stagnation period between 1998 and 2005. For this period, the results suggest that the redistribution component played a bigger role in explaining poverty changes. For example, for the poverty index $\mathrm{FGT}_{2}$ the redistributive component accounted for $82 \%$ and $66 \%$ of the overall poverty change between 1998 and 2005 in case of income and consumption, respectively. This conclusion reinforces the analysis of basic income growth and inequality changes statistics from Tables 1-2. These tables suggest that during this sub-period mean income and consumption expenditures declined slightly, while the increases in income and consumption inequality were more profound. Similar conclusions can be drawn for other FGT indices under study. Therefore, we may conclude that the 
primary reason for the significant rise in poverty in Poland during 1998-2005 was a substantial rise in income and consumption inequality.

Table 5. Growth-redistribution poverty decompositions using the Shapley approach

\begin{tabular}{lllll}
\hline & $\begin{array}{l}\text { Poverty } \\
\text { index }\end{array}$ & $\begin{array}{l}\text { Total change in } \\
\text { poverty }\end{array}$ & $\begin{array}{l}\text { Growth } \\
\text { component }\end{array}$ & $\begin{array}{l}\text { Redistribution } \\
\text { component }\end{array}$ \\
\hline Income & & & & \\
$1998-2005$ & $\mathrm{FGT}_{0}$ & $0.0515^{*}$ & $0.0135^{*}$ & $0.0380^{*}$ \\
& $\mathrm{FGT}_{1}$ & $0.0208^{*}$ & $0.0043^{*}$ & $0.0165^{*}$ \\
& $\mathrm{FGT}_{2}$ & $0.0103^{*}$ & $0.0019^{*}$ & $0.0084^{*}$ \\
& & & & \\
& & & & \\
& $\mathrm{FGT}_{0}$ & $-0.1446^{*}$ & $-0.1302^{*}$ & $-0.0144^{*}$ \\
& $\mathrm{FGT}_{1}$ & $-0.0451^{*}$ & $-0.0386^{*}$ & $0.0046^{*}$ \\
& $\mathrm{FGT}_{2}$ & $-0.0194^{*}$ & $-0.0163^{*}$ & $-0.0031^{*}$ \\
Consumption & & & & \\
& $\mathrm{FGT}_{0}$ & $0.0409^{*}$ & $0.0198^{*}$ & $0.0211^{*}$ \\
& $\mathrm{FGT}_{1}$ & $0.0186^{*}$ & $0.0074^{*}$ & $0.0112^{*}$ \\
& $\mathrm{FGT}_{2}$ & $0.0094^{*}$ & $0.0033^{*}$ & $0.0061^{*}$ \\
& & & & \\
& $\mathrm{FGT}_{0}$ & $-0.1301^{*}$ & $-0.1331^{*}$ & 0.0030 \\
& $\mathrm{FGT}_{1}$ & $-0.0442^{*}$ & $-0.0447^{*}$ & 0.0005 \\
& $\mathrm{FGT}_{2}$ & $-0.0194^{*}$ & $-0.0193^{*}$ & -0.0001 \\
\hline
\end{tabular}

Source: Own calculations using the HBS data.

Notes: * denotes statistical significance at the $95 \%$ confidence level calculated using asymptotic methods and DASP software (Araar and Duclos 2009).

For the fast-growth period between 2005 and 2008 the results suggest that almost all of poverty changes can be accounted for by income and consumption growth. In fact, changes in the redistribution component are statistically insignificant in case of consumption distribution, while in case of income distribution the growth component explains from 84 to $90 \%$ of total poverty changes depending on the FGT index used. This confirms the inspection of trends in means of major distributional statistics from Tables 1-2: standard of living in Poland rose substantially between 2005 and 2008 without worsening of income and consumption distribution. This contributed to a rapid fall in absolute poverty irrespectively of the way poverty is being measured.

Further insights into the nature of factors accounting for recent poverty changes in Poland can be gained from sectoral decompositions of poverty shown in Table 6. It shows results of the decomposition of poverty changes across five basic socio-economic groups defined in the HBS, performed for consumption expenditures and using the $\mathrm{FGT}_{2}$ index of poverty. ${ }^{8}$ For both sub-periods studied the sum of withinsector poverty effects is much larger than the sum of across-sector poverty effects. We start with the analysis of sub-period of stagnation during 1998-2005. The striking fact about this period is the dramatic fall in the proportion of persons belonging to the category of farmers (from $20 \%$ in 1998 to $7 \%$ in 2005). According to the HBS classification, households belong to this category if agricultural income is their

${ }^{8}$ Results for income distribution and other FGT indices were similar to that for consumption and the $\mathrm{FGT}_{2}$ index. They are available from author upon request. 
exclusive or main source of maintenance. The radical decline in farmers' population corresponds therefore simply to the rising diversification of sources of income for rural population. During 1998-2005 the additional income from other sources (i.e. labour, pensions, social transfers) exceeded agricultural income for many of these households. The separate effect of this change on total poverty was highly positive (i.e. poverty-reducing) as the average poverty measured by the $\mathrm{FGT}_{2}$ index among farmers was much higher (0.049 in 1998) than for the whole population (0.031 in 1998). However, this positive effect was outdone by other negative (i.e. povertyincreasing) within-sector and across-sector effects. In particular, the increase of poverty as measured by the $\mathrm{FGT}_{2}$ among the labourers was equal to $68.5 \%$ of total poverty increase during the analyzed sub-period.

Table 6. Sectoral decomposition of poverty changes for consumption expenditures and $\mathrm{FGT}_{2}$ index of poverty

\begin{tabular}{llllllll}
\hline Group & $\begin{array}{l}\mathrm{FGT}_{2} \\
\text { at } t\end{array}$ & $\begin{array}{l}\text { Pop. } \\
\text { share } \\
\text { at } t\end{array}$ & $\begin{array}{l}\mathrm{FGT}_{2} \\
\text { at } t+n\end{array}$ & $\begin{array}{l}\text { Pop. } \\
\text { share } \\
\text { at } t+n\end{array}$ & $\begin{array}{l}\text { Within- } \\
\text { sectoral } \\
\text { effect }\end{array}$ & $\begin{array}{l}\text { Across- } \\
\text { sectoral } \\
\text { effect }\end{array}$ & $\begin{array}{l}\text { Total } \\
\text { effect }\end{array}$ \\
\hline $\begin{array}{l}\text { 1998-2005 } \\
\text { Laborers }\end{array}$ & 0.023 & 44.87 & 0.036 & 51.32 & $68.54^{*}$ & $20.23^{*}$ & $88.77^{*}$ \\
Farmers & 0.049 & 19.97 & 0.056 & 7.04 & $10.47^{*}$ & $-71.92^{*}$ & $-61.45^{*}$ \\
Self-emp. & 0.016 & 7.46 & 0.023 & 7.02 & $5.11^{*}$ & -0.92 & $4.19^{*}$ \\
Pensioners & 0.026 & 24.92 & 0.033 & 27.58 & $19.90^{*}$ & $8.42^{*}$ & $28.31^{*}$ \\
Non-earners & 0.106 & 2.78 & 0.096 & 7.03 & -5.56 & $45.73^{*}$ & $40.18^{*}$ \\
All & 0.031 & 100.00 & 0.040 & 100.00 & 98.46 & 1.54 & 100.00 \\
2005-2008 & & & & & & & \\
Laborers & 0.036 & 51.32 & 0.019 & 58.68 & $48.25^{*}$ & $-10.49^{*}$ & $37.76^{*}$ \\
Farmers & 0.056 & 7.04 & 0.033 & 6.25 & $8.00^{*}$ & $1.80^{*}$ & $9.80^{*}$ \\
Self-emp. & 0.023 & 7.02 & 0.009 & 7.75 & $5.34^{*}$ & $-0.60^{*}$ & $4.75^{*}$ \\
Pensioners & 0.033 & 27.58 & 0.020 & 23.95 & $17.72^{*}$ & $4.99^{*}$ & $22.70^{*}$ \\
Non-earners & 0.096 & 7.03 & 0.056 & 3.37 & $10.68^{*}$ & $14.30^{*}$ & $24.98^{*}$ \\
All & 0.040 & 100.00 & 0.021 & 100.00 & 90.00 & 10.00 & 100.00 \\
\hline
\end{tabular}

Source: Own calculations using the HBS data.

Notes: The figures in last three columns are expressed as percentages of the overall poverty change. Poverty change during 1998-2005 period was positive (poverty increased), while it was negative during 2005-2008. * denotes statistical significance at the $95 \%$ confidence level calculated using bootstrap methods (see Notes to Table 3 ).

Similarly, the population of non-earners (i.e. households for which the main source of income were social transfers) increased from $2.8 \%$ to $7 \%$ and the effect of this change was approximately equal to $46 \%$ of the total poverty increase. Poverty among pensioners also rose substantially ( $19.9 \%$ of total poverty increase). In overall, the results suggest that during the stagnation sub-period poverty increased most because of stagnant wages of labourers and incomes of pensioners as well as because the number of non-earners increased significantly due to the huge rise in unemployment rate (see Table 1). Poverty would have increase even more, if a large proportion of farmers did not find additional non-farm sources of income.

During the fast-growth sub-period between 2005 and 2008, the single most important effect was within-sectoral decrease of poverty as measured by the $\mathrm{FGT}_{2}$ 
index among labourers ( $48.3 \%$ of total poverty decrease). At the same time the rise in the labourers population share (from $51.3 \%$ in 2005 to $58.7 \%$ in 2008) contributed to the increase of $10.5 \%$ of total poverty, since the poverty among labourers remained lower than the national average throughout the period.

Other important effects include the fall in poverty among pensioners $(17.7 \%$ of total poverty change) and both within-sectoral and across-sectoral effects for nonearners, which accounted for $10.7 \%$ and $14.3 \%$ of total poverty decrease, respectively. In overall, the most significant poverty-reducing effects during this period were the fast growth of wages (and other sources of income) for labourers, improving situation of pensioners and decreasing number of non-earners due to the radical drop in the unemployment rate (see Table 1).

Finally, Table 7 delivers results concerning poverty impact and poverty effectiveness of various income sources summing up to the net disposable income. The analysis is performed for the $\mathrm{FGT}_{0}$ and $\mathrm{FGT}_{1}$ poverty indices. Disposable income is divided into market income (including wages and salaries, self-employment income, farm income and cash property income), social insurance (including old age pensions, disability benefits, family pensions, etc.), social assistance (including family and nursing benefits, housing subsidies, welfare cash payments, unemployment benefits, etc.) and other sources (including indemnities, gifts, pensions from abroad, etc.).

Table 7. Poverty impact and poverty effectiveness of different disposable income sources

\begin{tabular}{lllllll}
\hline Income source & $\pi_{\alpha}\left(y_{i}, z\right)$ & \multicolumn{5}{c}{$\Gamma_{\alpha}\left(y_{i}, z\right)$} \\
\cline { 2 - 7 } & 1998 & 2005 & 2008 & 1998 & 2005 & 2008 \\
\hline$F G T_{0}$ & & & & & & \\
Market income & 63.4 & 59.8 & 68.3 & 47.0 & 43.2 & 40.5 \\
Social insurance & 30.9 & 30.2 & 25.2 & 49.2 & 48.3 & 44.5 \\
Social assistance & 2.2 & 5.3 & 3.5 & 36.6 & 37.9 & 40.0 \\
Other sources & 3.5 & 4.7 & 3.0 & 30.6 & 33.3 & 26.1 \\
$F G T_{1}$ & & & & & & \\
Market income & 61.6 & 56.7 & 63.4 & 57.0 & 52.1 & 42.0 \\
Social insurance & 30.1 & 28.9 & 26.4 & 60.0 & 58.7 & 51.9 \\
Social assistance & 3.7 & 8.4 & 5.6 & 75.6 & 77.4 & 69.9 \\
Other sources & 4.6 & 6.0 & 4.6 & 50.1 & 52.8 & 44.7 \\
\hline
\end{tabular}

Source: Own calculations using the HBS data.

Notes: Calculated using DASP software (Araar and Duclos 2009). Standard errors for all estimates are very small and we do not report them.

Independently of the poverty index used, the poverty impact of market income and social assistance follow the business cycle. The poverty impact of market income decreased somewhat during the stagnation sub-period between 1998 and 2005 and increased significantly during fast growth after 2005. The opposite can be observed for social assistance. The poverty impact of social insurance is gradually declining throughout the analyzed period. Turning to the poverty effectiveness of disposable income components, we can observe that for the poverty incidence (as measured by the headcount ratio) social insurance remained the most effective income source throughout the period under study with market income being almost equally effective. The effectiveness of social assistance was increasing through the period and in 2008 
its effectiveness is essentially the same as that of market income. If one would want to use the $\mathrm{FGT}_{1}$ index of poverty, which accounts not only for the extent, but also for the intensity of poverty (poverty gap), then the conclusions about effectiveness of various income sources are different - social assistance becomes by far the most cost-efficient income component. ${ }^{9}$ Therefore, we may conclude that social assistance expenditures in Poland have been the most cost-effective income source in reducing intensity of poverty, but that they are at most equally effective as other income components in reducing the extent of poverty in Poland.

\section{Conclusions}

This paper applied a number of analytical decompositions of poverty and poverty changes in order to study what lies behind recent trends in absolute poverty in Poland. The decade between 1998 and 2008 was divided into a sub-period of stagnation from 1998 to 2005 and a sub-period of fast-growth since 2005. The main findings are the following. During the stagnation period absolute poverty rate has increased in Poland by $12 \%$ (consumption) and $22 \%$ (income). This effect was outdone by a rapid fall in absolute poverty rate between 2005 and 2008, when poverty rate dropped by $34 \%$ (consumption) and 50\% (income). The rise of absolute poverty during the first subperiod was mainly due to increasing economic inequality, while the radical fall of absolute poverty since 2005 was associated almost exclusively with rapid economic growth.

The insights from sectoral decompositions of poverty changes suggest that the overall poverty increase before 2005 can be largely explained by stagnant wages and pensions as well as by growing unemployment. One factor that played an important poverty-reducing role in this period was growing diversification of income sources among farmers. Fast growth of wages, improving situation of pensioners and a large decrease in the unemployment rate are responsible for radical drop in absolute poverty between 2005 and 2008. Social insurance (i.e. old-age pensions, disability benefits, etc.) is the most effective income source in Poland in reducing the extent of poverty as measured by the poverty rate (poverty headcount ratio). On the other hand, the most effective income source in reducing the intensity of poverty (as measured by the poverty gap index) is the social assistance.

\section{References}

Araar, A., and Duclos, J.-Y., 2009. User manual for Stata package DASP: version 2.1. PEP, World Bank, UNDP and Université Laval.

Bibi, S., and Duclos, J.-Y., 2010. A comparison of the poverty impact of transfers, taxes and market income across five OECD countries. Bulletin of Economic Research, 62 (4), 387-406.

Bourguignon, F., 2004. The poverty-growth-inequality triangle. World Bank, mimeo.

${ }^{9}$ Similar conclusions are achieved by Szulc (2009) in his analysis of the effectiveness of social transfers in Poland. 
CSO (Central Statistical Office), 2009. Household budget surveys in 2008. Warszawa: CSO.

Chakravarty, S.R., 2009. Inequality, Polarization and Poverty. Advances in Distributional Analysis. New York: Springer.

Chen, S., and Ravallion, M., 2007. Absolute poverty measures for the developing world, 1981-2004. Proceedings of the National Academy of Sciences of the United States of America, 104 (43), 16757-16762.

Datt, G, and Ravallion, M., 1992. Growth and redistribution components of changes in poverty measures: a decomposition with application to Brazil and India in the 1980s. Journal of Development Economics, 38 (2), 275-95.

Duclos, J.-Y. and Araar, A., 2006. Poverty and equity: measurement, policy and estimation with DAD. New York: Springer, and Ottawa: International Development Research Centre.

Foster, J., Greer. J., and Thorbecke, E., 1984. A class of decomposable poverty measures. Econometrica, 52 (3), 761-776.

Howes, S., and Lanjouw, J.O., 1998. Does sample design matter for poverty comparison? Review of Income and Wealth, 44 (1), 99-109.

Huppi, M., and Ravallion, M. 1991. The sectoral structure of poverty in Indonesia during an adjustment period: Evidence for Indonesia in the mid-1980s. World Development, 19(12), 1653-1678.

Kakwani, N., 2000. On measuring growth and inequality components of poverty with application to Thailand. Journal of Quantitative Economics, 16 (1), 67-79.

Kolenikov, S., 2010. Resampling variance estimation for complex survey data. Stata Journal, 10 (2), 165-199.

Kordos, J., Lednicki, B., and Zyra, M., 2002. The household sample surveys in Poland. Statistics in Transition, 5 (4), 555-589.

Morawski, L. and Myck, M., 2010. Distributional effects of the Polish Child Tax Credit and its potential reforms. Centre for Economic Analysis, CenEA Microsimulation Report MR01/10.

Osberg, L. and $\mathrm{Xu}, \mathrm{K} ., 2000$. International comparisons of poverty intensity: index decomposition and bootstrap inference. Journal of Human Resources, 35 (1), $51-81$.

Paci, P., M. J. Sasin, and J. Verbeek (2004) "Economic growth, income distribution, and poverty in Poland during transition," December. World Bank Policy Research Working Paper 3467, The World Bank.

Ravallion, M. (2003) "Measuring aggregate welfare in developing countries: How well do national accounts and surveys agree?," Review of Economics and Statistics, Vol. 85, No. 3, pp. 645-652.

Sen, A., 1976. Poverty: an ordinal approach to measurement. Econometrica, 44 (2), 219-231.

Shorrocks, A., 1999. Decomposition procedures for distributional analysis: A unified framework based on the Shapley value, University of Essex, mimeo.

Shorrocks, A., 1995. Revisiting the Sen poverty index. Econometrica, 63 (5), $1225-1230$.

Szulc, A., 2000. Economic transition, poverty and inequality: Poland in the 1990s. Statistics in transition, 4, 997-1017.

Szulc, A., 2006. Poverty in Poland during the 1990s: are the results robust? Review of Income and Wealth, 52 (3), 423-448. 
Szulc, A., 2008. Checking the consistency of poverty in Poland: 1997-2003 evidence, Post-Communist Economies, 20 (1), 33-55.

Szulc, A., 2009. Social policy and poverty: checking the efficiency of the social assistance system in Poland. Institute of Statistics and Demography, Warsaw School of Economics, Working Paper No. 1/2009.

Thon, D., 1979. On measuring poverty. Review of Income and Wealth, 25, 429-440.

Watts, H., 1968. An economic definition of poverty. In: D.P. Moynihan, ed. On understanding poverty. New York: Basic Books, 316-329.

World Bank, 2000. Making transition work for everyone: poverty and inequality in Europe and Central Asia. Washington, D.C.: World Bank.

World Bank, 2005. Growth, poverty, and inequality: Eastern Europe and the Former Soviet Union. Washington, D.C.: World Bank.

Zheng, B., 1997. Aggregate poverty measures. Journal of Economic Surveys, 11 (2), $123-162$. 


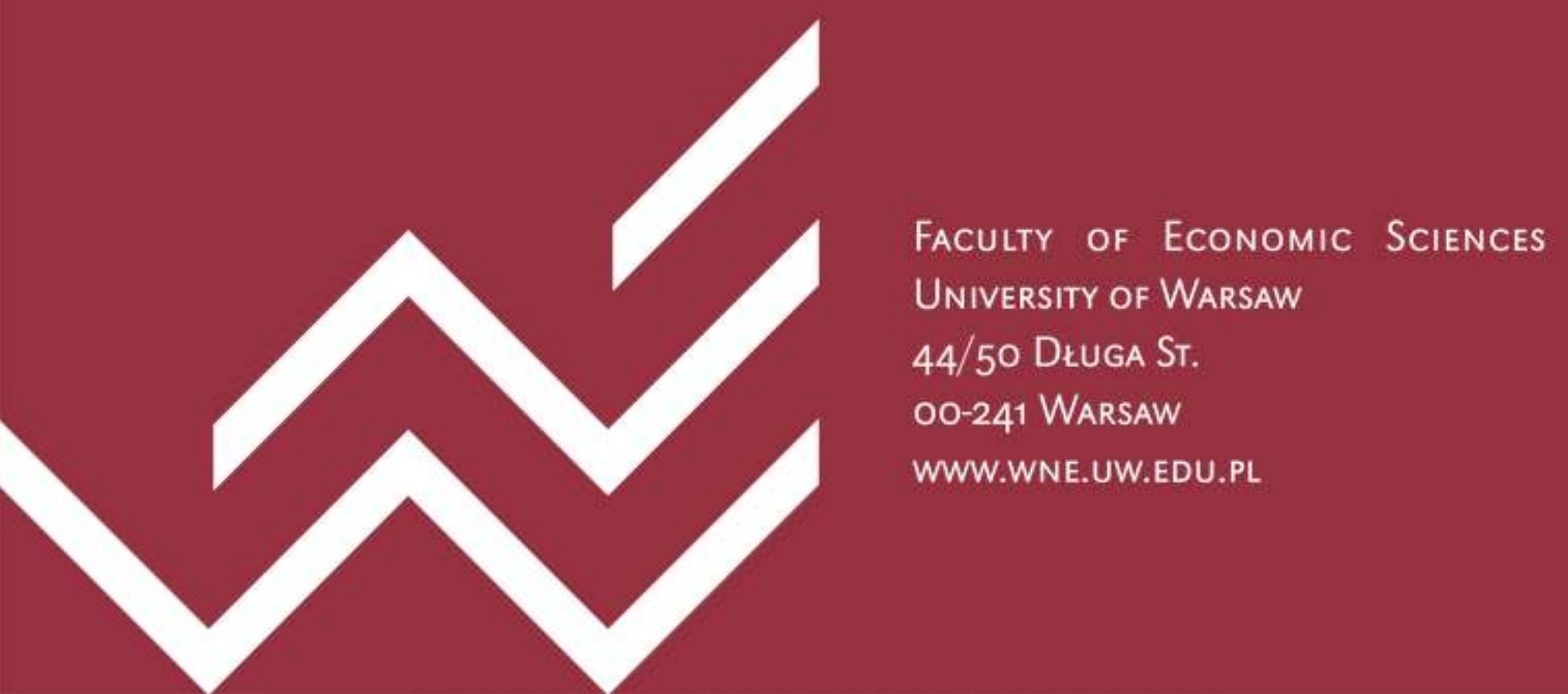

